\title{
ACER3 wt Allele
}

National Cancer Institute

\section{Source}

National Cancer Institute. ACER3 wt Allele. NCI Thesaurus. Code C103897.

Human ACER3 wild-type allele is located in the vicinity of $11 \mathrm{q} 13.5$ and is approximately $166 \mathrm{~kb}$ in length. This allele, which encodes alkaline ceramidase 3 protein, plays a role in phytoceramide metabolism. 